Missio Ecclesiae
ISSN 2086-5368 (Print)
ISSN 2086-5368 (Online)
https://jurnal.i3batu.ac.id/index.php/me
Vol. 9, No.2, pp. 17-44, 2020

\title{
Integrasi Kristologi dan Misiologi Berdasarkan Lukas 24:44- 49 Bagi Pelayanan Misi di Gereja Persekutuan Oikoumene Umat Kristen (POUK) ICHTHUS Bumi Dirgantara Permai - Bekasi
}

\author{
Galuh Pandandari, ${ }^{a}$ Erni M.C. Efruan ${ }^{b}$ \\ a*STT Arrabona, galuhruku@gmail.com, \\ ${ }^{b}$ Institut Injil Indonesia, erniefruan63@gmail.com,erni_i3@yahoo.co.id

\section{INFO ARTIKEL ABSTRAK}

\section{Sejarah Artikel:}

Diterima :

06 Oktober 2020

Direvisi :

07 Oktober 2020

Disetujui:

30 Oktober 2020

Dipublikasi:

30 Oktober 2020

\section{Kata Kunci:}

Integrasi, Kristologi,

Misiologi, Misi dan

Gereja.

$---=-\cdots=-$

Keywords:

Integration,

Christology,

Missiology, Mission, Church

--- - - - - - -

\begin{abstract}
Penulisan artikel ini bertujuan untuk mengemukakan sebuah model dari integrasi Kristologi dan Misiologi, dengan menggunakan desain sequential explanatory.

Beberapa prinsip yang terdapat dalam model tersebut adalah: (1) Kristologi dan Misiologi yang Alkitabiah, (2) Kristologi yang misiologis dan Misiologi yang kristologis, (3) Kristologi tanpa Misiologi menjadi Kristologi tanpa sasaran, Misiologi tanpa Kristologi menjadi Misiologi tanpa dasar, (4) Integrasi Kristologi dan Misiologi meningkatkan mutu pelayanan misi, (5) Integrasi Kristologi dan Misiologi yang diajarkan secara maksimal menghasilkan keterlibatan dalam misi global, (6) Kristologi dan Misiologi yang terintegrasi melalui ketaatan menjadi Saksi Kristus, dan (7) Efektivitas Integrasi Kristologi dan Misiologi bergantung pada kuasa Roh Kudus.

Rekomendasi diberikan kepada Gembala Jemaat, Para Pengajar dan Penggiat Misi, dalam mengemban misi Allah sampai Parousia.
\end{abstract}

\begin{abstract}
This article is aimed to explain a model of integration between christology and missiology, using sequential explanatory design.

Some of the principles contained in this model are: 1) christology and missiology bound on biblical base, 2) missiological christology and christological missiology, 3) Christology without missiology is a targetless christology, missiology without christology is a baseless missiology, 4) integration of christology and misiology improves ministry of mission, 5) integration of christology and missiology that maximally taught produces involvement in global mission, 6) integrated christology and missiology thru obedience as Christ's witness, and 7) effectivity of the integration between christology and missiology depends on the power of the Spirit

Recommendation is granted to pastors, instructors of fellowship groups and mission activists in accomplishing God's mission until Parousia
\end{abstract}

\section{PENDAHULUAN}

Kehidupan rohani yang sehat adalah aplikasi dari doktrin yang sehat. 
Keseimbangan dan keutuhan Teologi Kristen seharusnya tetap dipertahankan, namun faktanya para teolog jatuh pada spesialisasi yang sempit dan parsial. Menurut John R.W. Stott, ada teolog yang berpendapat bahwa mereka dapat berteologia, sekalipun terisolasi dengan dunia atau tanpa mempersoalkan konteks, teologi dapat diformulasikan (R.W Stott, 1996, p. 12) Ada keengganan teologi sistematika menjadi orthophraxis, karena rumusanrumusan teologi seringkali tidak berurusan dengan gereja atau dunia. Menanggapi hal ini Kantzer mengemukakan bahwa teologi sistematika tidak boleh dipisahkan dari teologi praktika, tetapi teologi sistematika adalah praktika (Kantzer, 1996, pp. 34-35). Secara lebih spesifik, kristologi sebagai salah satu disiplin ilmu teologi sistematika, tidak dapat dipisahkan dari teologi praktika karena Kristus adalah pusat teologi. Misi dibangun di atas dasar misi Tuhan Yesus melalui karya-Nya yang sempurna demi keselamatan manusia. Charles Van Engen menyatakan demikian, "Missiology is a unified whole; it is a discipline in its own right, centered in Jesus Christ and His mission. As the church participatesin the mission of Jesus Christ, it participates in God's mission in God's world through the power of the Holy Spirit" (Van Engen, 1996, p. 19) Tentang hal ini, Adrian Saravia menegaskan bahwa Amanat Agung yang berpusat pada Kristus tetap relevan untuk semua pengikut Kristus sepanjang masa (Verkuyl \& Cooper, 1978, p. 20) Misi teraktualisasi di dalam dan melalui pribadi dan karya Tuhan Yesus, sejak inkarnasi-Nya, kematian, kebangkitan, kenaikan-Nya ke surga hingga kedatangan-Nya kembali.

Dalam sejarah gereja, para bapak gereja memformulasikan teologi sistematika mereka untuk kepentingan misi bagi orang yang belum percaya. Namun di abad pertengahan, teologi sistematika hanya ditujukan untuk kepentingan gereja. Karakteristik misiologi tidak nampak dalam teologi sistematika, diganti dengan kepentingan akademik, kepuasan intelektual dan apologetic (Bosch, 1991, pp. 321-328). Di masa reformasi Luther, teologi sistematika digunakan untuk pembelaan terhadap ajaran Gereja Katolik, namun Calvin tidak menghapus Amanat Agung, bahkan ia menegaskan tentang misi gereja yang holistik dalam kerajaan Allah. Kepeduliannya adalah menyebarkan pemahaman iman yang Alkitabiah di Eropa dan hal ini menunjukkan semangat misinya. Pada era misi modern, gereja mulai menggaungkan tentang kontekstualisasi, karena teologi sistematika gereja cenderung hanya berurusan dengan doktrin akademik (Van Engen, 2000, p. 926). Selanjutnya pada masa kini, beberapa gereja yang hanya terfokus pada pengajaran di dalam, dan mengabaikan misi, mengalami kehancuran. Sebagai contoh Crystal Cathedral Church di Los Angeles, yang didirikan oleh Robert H. Sculler, mulanya adalah reformed church kemudian menekankan teologi sukses, akhirnya mengalami kehancuran di tahun 2012 (www. Getreligion.Org, n.d.) Atau "mega-church" di negara-negara selatan (dunia ketiga) dengan dalil three formula, yaitu self propagating, self government dan self supporting. Mereka menciptakan budaya homogen, seperti globalisasi yang berarti homogenisasi dan meniadakan misi lintas budaya (Jenkins, 2011). Namun ada pula gereja-gereja yang melakukan misi tanpa dasar yang kuat atau tanpa pemahaman Alkitabiah tentang misi, sehingga misi dilihat sebagai tanggung jawab sosial, keadilan dan kemanusiaan. Unsur misi lintas budaya dan misi penginjilan bagi penebusan telah diganti dengan misi lokal, kesejahteraan dan misi untuk membangun kerajaan sendiri (Elwood, 1992, pp. 173-218). Gereja seharusnya memiliki pengajaran kristologi yang bermuara pada misiologi, sehingga menghasilkan jemaat missioner yang memberitakan Kristus kepada dunia.

Gereja POUK ICHTHUS Bumi Dirgantara Permai memberikan pengajaran kepada jemaat agar memiliki pemahaman yang utuh tentang kristologi dan misiologi. Pengajaran diberikan melalui kelas pembinaan, khotbah-khotbah bertujuan, seminar/kursus dan juga Kelompok Tumbuh Bersama (KTB). Idealnya, muara dari semua pengajaran yang telah diberikan adalah jemaat memiliki praktik kehidupan misi yang yang berpusat kepada 
Kristus. Masalah yang ditemukan di lapangan menunjukkan keterlibatan jemaat dalam praktik misi masih belum maksimal. Dalam pra penelitian terhadap 111 jemaat yang diambil secara acak sebagai sampel untuk melihat rasio perbandingan antara pemahaman dan praktik Kristologi dan Misiologi jemaat, didapati bahwa ada kesenjangan yang cukup tinggi di antara sebagian besar jemaat (lembar kuesioner terlampir).

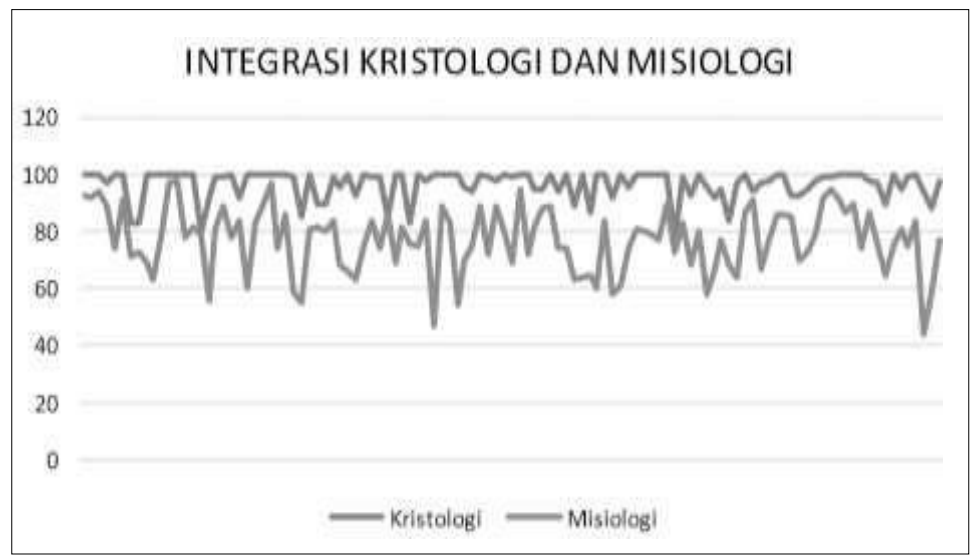

Diagram 1. Pengajaran dan Praktik Kristologi dan Misiologi

Seharusnya pemahaman yang utuh menghasilkan praktik hidup yang maksimal (seimbang). Namun faktanya, dari 111 responden yang mengisi kuesioner pengajaran dan praktik Kristologi dan Misiologi, penulis mengelompokan sampel sebagai berikut :

- Kelompok A: memiliki pemahaman dan praktik dengan nilai tinggi.

- Kelompok B: memiliki pemahaman dengan nilai tinggi dan praktik dengan nilai sedang.

- Kelompok C: memiliki pemahaman dan praktik dengan nilai sedang.

- Kelompok D: memiliki pemahaman dengan nilai sedang dan praktik dengan nilai rendah.

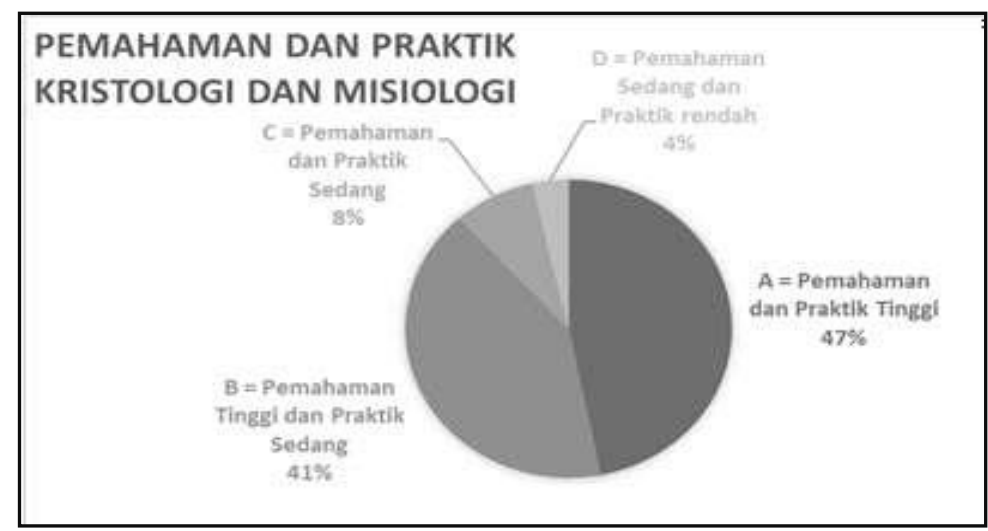

Diagram 2. Kelompok Pemahaman dan Praktik Kristologi dan Misiologi

Dengan melihat Grafik di atas, diketahui bahwa hanya kelompok A (47\%) yang memiliki pemahaman dan praktik kristologi dan misiologi tinggi dan seimbang. Permasalahan dapat ditemukan di dalam Kelompok B, C dan D, (53\%).

Pemahaman Kristologi dan Misiologi yang seimbang akan menghasilkan keluaran (output) yang maksimal, kemudian terimplementasi di lapangan (outcomes). Permasalahan menjadi semakin tajam karena hampir seluruh responden terlibat dalam pelayanan dan mengikuti hampir semua sarana penanaman pemahaman kristologi dan misiologi. 


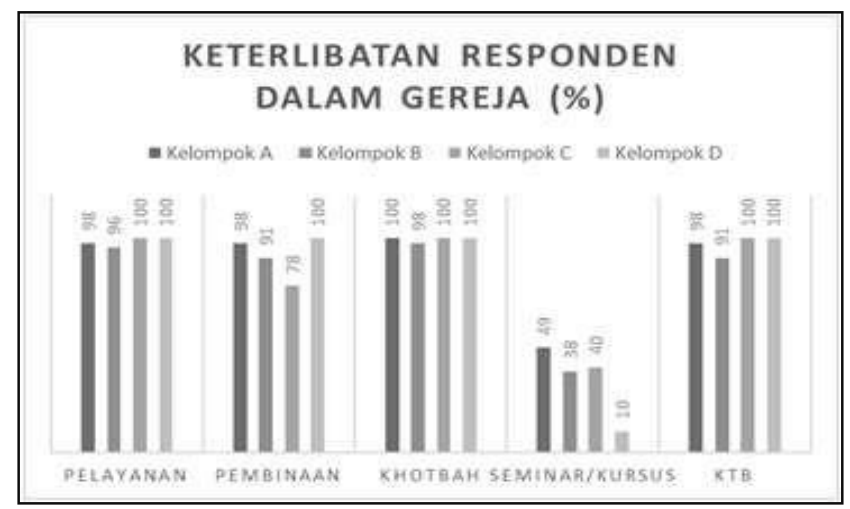

Diagram 3. Keterlibatan Responden dalam Gereja

Melalui Diagram ini diketahui bahwa Kelompok A, B, C dan D terdiri dari responden yang aktif dalam pelayanan (99\%) dan giat mengikuti khotbah baik di kebaktian umum maupun kebaktian lain (99\%). Program KTB (97\%) dan kelas pembinaan (92\%) pun menjadi wadah yang diminati oleh para responden. Sedangkan seminar/kursus merupakan program yang kurang diminati (34\%).

Selanjutnya, Untuk melihat kesatuan antara pengajaran dan praktik kristologi dan misiologi yang dilakukan oleh gereja ini, telah dilakukan sebuah penelitian yang dibahas berdasarkan Lukas 24:44-49 dalam kajian teori.

\section{KAJIAN LITERATUR}

Teks Lukas 24:44-49 merupakan percakapan pribadi Yesus dengan para murid-Nya dengan tujuan mengingatkan kembali segala sesuatu yang telah dinyatakan dan diperintahkan-Nya kepada para murid, sebagai acuan pengajaran dan praktik hidup pengikut Kristus. Untuk lebih mendalami bagian ini, maka perlu dilakukan eksegesis teks tersebut.

\section{a. Eksegesis Teks}

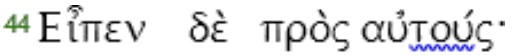

And he said unto them,

Semua Injil mencatat amanat terakhir Yesus kepada murid-murid-Nya, yang mengarah kepada misi ke seluruh dunia. Jadi, di bagian ini Yesus mengingatkan para muridnya tentang apa yang telah dikatakan-Nya kepada mereka selama pelayanan-Nya di bumi dan mengingatkan mereka inti dari pengajaran dan praktik hidup yang sesuai kehendak-Nya.

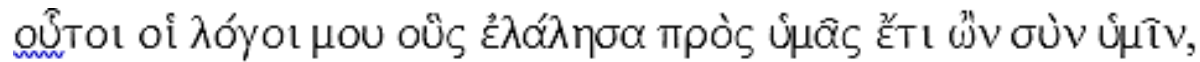
These are the words which I spake unto you yet while I was yet with you,

Yang dimaksudkan dengan "kata-kata ini" bukanlah ajaran Yesus yang bersifat umum tetapi ajaran yang bersifat khusus yaitu tentang Yesus dan karya-Nya dan bagaimana para murid melakukan perintah-Nya (Lukas 9:22, 44; 17:25; 18: 31$33 ; 22: 37)$. "Kata-kata ini" menunjuk pada semua hal yang akan disampaikan pada ayat-ayat selanjutnya, secara khusus hingga ayat 47. Selanjutnya, "ketika Aku masih 
bersamamu" menunjukkan bahwa Kristus yang bangkit adalah pribadi yang sama dengan "Yesus yang historis" (Luk 24:39). Hal ini mengungkapkan bahwa suatu periode baru di mana Yesus tidak lagi "bersama mereka", dalam tubuh kemanusiaanNya. Lukas meyakini kebangkitan Kristus, sebagai bukti eksistensi keilahian-Nya (Bock, 2010).

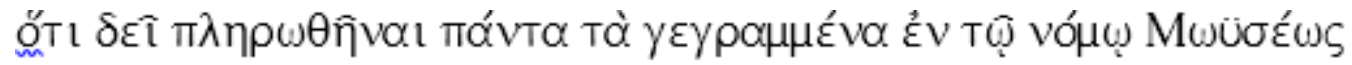 that all things must be fulfilled. which were written in the law of Moses
}

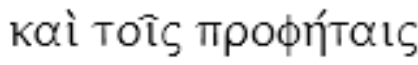 \\ and in the prophets,

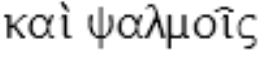 \\ and in the psalms, \\ $\pi \varepsilon \rho \grave{~ \varepsilon ૈ u o u ̂ . ~}$ \\ concerning me.
}

Bagi Lukas, Perjanjian Lama adalah buku yang terfokus kepada Kristus, dari awal sampai akhir. Istilah "semua yang ada tertulis" menunjuk pada Kristus, karya dan perintah-Nya bagi para pengikut-Nya. Hal inilah yang tidak dipahami oleh para murid selama pelayanan Yesus. Ia menegaskan bahwa diri-Nya adalah tema dari semua wahyu kuno. Pada tiga bagian penting dalam Perjanjian Lama yang sekarang disebut; yaitu, Hukum, Nabi, dan Hagiographa, menyatakan tentang kematian, kebangkitan dan pemberitaan tentang Yesus (Maclaren, 2008, p. 44) Fakta ini ingin menunjukan tentang keberadaan Yesus pre eksistensi, bahwa Ia telah ada di masa Perjanjian Lama, bahkan sebelum segala sesuatu jadi.

Lukas menyoroti rancangan ilahi dengan menggunakan istilah dei, "itu perlu". Kata ini menyatakan "karakter keharusan atau paksaan" dalam suatu peristiwa. Kittel mengemukakan, "this word expresses the "character of necessity or compulsion" in an event. The term itself does not denote the authority which imparts this character. It is thus given its precise significance when conjoined with this power"(Kittel, Gerhard, Bromiley, Geogfresy William; Friedrich, 1964) "Itu perlu," diterjemahkan "berperilaku," dalam Lukas 24:46 (bahwa Kristus) "harus" (menderita). Dei mengungkapkan kebutuhan logis, opheilo, kewajiban moral dapat diterjemahkan "seharusnya," yang mengungkapkan suatu kebutuhan yang dihasilkan. Tentang hal ini Vine menyatakan, "it is necessary," is rendered "behoved," in Luke 24:46; RV, (that the Christ) "should" (suffer). Dei expresses a logical necessity, opheilo, a moral obligation; Jas. 3:10, "ought," which expresses a need resulting from the fitness of things (Viner, W.E., Unger, Merril F., White, 1996, p. 60). Seperti halnya infinitif bahasa Inggris, infinitif bahasa Yunani dapat digunakan seperti frasa kata benda ("Lebih baik hidup daripada mati"), serta untuk mencerminkan tujuan atau hasil ("Ini dilakukan untuk memenuhi apa yang dikatakan nabi"). Dalam hal ini, penggenapan tentang Kristus yang dimaksudkan dengan kata "harus" adalah 3 infinitif yang diuraikan dalam ayat-ayat selanjutnya (46-47). Kehidupan Yesus merupakan penggenapan dari Kitab Suci. "Segala sesuatu harus dipenuhi yang tertulis tentang Aku dalam Hukum Musa, para nabi dan mazmur." (Clarke, 1999, p. 44) 
Ayat 44 mengungkapkan hal yang penting tentang keberadaan Yesus, baik pre eksistensi sebagaimana tertera dalam Perjanjian Lama, tetapi juga keberadaanNya setelah kebangkitan-Nya. Dalam hal ini, Lukas memberikan penekanan kuat tentang ke-Ilahian dan kemanusiaan Yesus. Kata "dei" atau "harus" juga menjadi kunci bagi penggalian terhadap teks ini. Ayat 44 merupakan kalimat utama yang didukung oleh frase-frase yang terdapat di dalam ayat selanjutnya. Inti dari Kitab Suci adalah nubuatan dan penggenapan tentang Kristus dan karya-Nya.

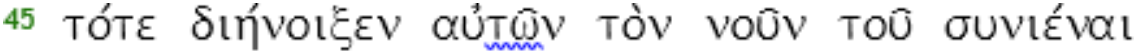

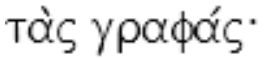

Then opened he their understanding, that they might understand the scriptures,

Kemudian Yesus menjelaskan Kitab Suci. Seperti seorang nabi-guru, Ia membuka pikiran mereka sehingga mereka dapat memahami Alkitab. Kata "membuka" digunakan untuk membuka pikiran seseorang agar dapat memahami sesuatu atau untuk membuka jiwa seseorang, yaitu untuk membangun sebuah pemahaman (Strong, 1996, p. 1272). Bagian ini dapat dikaitkan dengan pasal 24:25 ketika Yesus menggunakan istilah "bodoh" karena tidak mengerti apa yang telah dikatakan para nabi. Kata membuka pikiran bertujuan agar para murid memahami Alkitab sebagai firman Allah yang benar, dan untuk berbicara tentang Mesias. Kitab Suci dapat diterima secara umum sebagai wahyu Ilahi, dan penerapan yang tepat hanya dapat dilihat oleh cahaya Kristus.

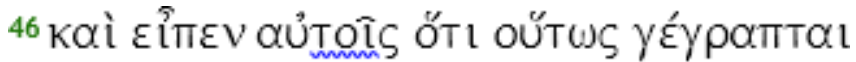 And said unto them, Thus it is written,}

Pandangan yang seksama pada sintaksis (hubungan antar frase) menunjukkan bahwa tiga tema mendominasi penjelasannya, karena ayat Luk 24: 46-47 diatur oleh tiga infinitif Yunani (pathein, anastēnai, kērychthēnai). Dalam ayat ini, ư $\tau$ vँ $\tau \alpha$

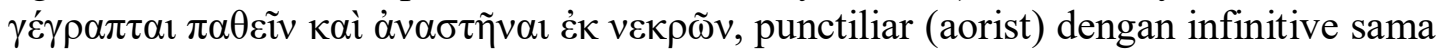
halnya dengan imperatif. Tentu saja tidak ada waktu di infinitive kecuali waktu relatif dalam wacana tidak langsung. Namun di sini menjelaskan tindakan tepat waktu yang diberikan oleh AORIST infinitive (Robertson, 2006, p. 856)

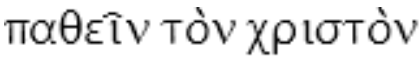 and (thus it behoved) Christ to suffer,}

Pertama, Kristus harus menderita. Untuk menjelaskan frase ini maka perlu memahami infinitif dalam bahasa Yunani, "Like the English infinitive, the Greek infinitive can be used like a noun phrase ("It is better to live than to die"), as well as to reflect purpose or result ("This was done to fulfil what the prophet said")" (Larry, n.d., p. 5795). Seperti halnya infinitif bahasa Inggris, infinitif bahasa Yunani dapat digunakan seperti frasa kata benda untuk mencerminkan tujuan atau hasil. Dalam teks ini dilakukan untuk memenuhi apa yang dikatakan nabi. Kitab 
Lukas mencatat banyak peristiwa penderitaan Kristus yang berakhir dengan kematian (Luk 9:22, Luk 9:44; Luk 17:25; Luk 18: 31-33; Luk 22:37). Kematiannya diantisipasi oleh Kitab Suci, bukan karena kesalahan manusia tetapi karena kerelaan-Nya untuk memberikan nyawa-Nya demi keselamatan manusia. Di bagian lain, Lukas mengutip Mazmur 118 dalam menggambarkan penolakan Yesus, bersama dengan bagian-bagian dari Yesaya 53 sehubungan dengan penderitaannya. Selain itu ia menyinggung Mazmur 22, Mazmur 31: 5 dan Mazmur 69 dalam kisah sengsara (Bock, 2010).

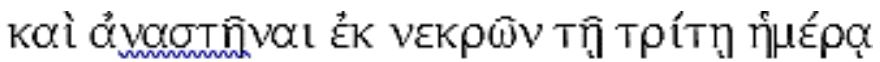 and to rise from the dead the third day:}

Kedua, Mesias harus dibangkitkan. Dalam konsep ini terikat Mazmur 16:10, Mazmur 110: 1 dan Mazmur 118: 22-26. Para murid mengalami kebenaran ini bahkan ketika Yesus berbicara tentang kebangkitan dari antara orang mati. Vine mengemukakan demikian, "of resurrection from the dead: of the resurrection of Christ" (Viner, W.E., Unger, Merril F., White, 1996, p. 36). Infinitif kedua adalah

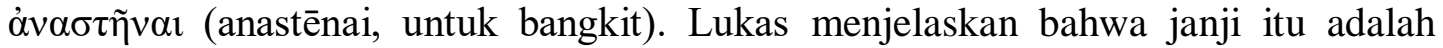
kebangkitan yang cepat, karena harapan Yahudi yang biasa adalah kebangkitan pada hari terakhir. Harapan ini dipertahankan dalam Kisah Para Rasul terutama berdasarkan dua teks: Mazmur 16:10 dan 110. Dengan Yesus yang menderita dan telah dibangkitkan oleh Allah, pesan kepada para murid dapat diterima (Bock, 1996, p. 1936). Dalam teks ini, Kristus mengutamakan kematian dan kebangkitan-Nya, dan sesudahnya buah yang kita peroleh dari keduanya. Pertobatan dan pengampunan dosa diperoleh karena manusia lama kita disalibkan dengan Kristus, (Rm. 6: 6,) sehingga dengan anugerah-Nya kita dapat naik ke kehidupan yang baru; dan karena dosa-dosa kita telah dihapuskan oleh pengorbanan kematiannya dan memperoleh kebenaran melalui kebangkitan-Nya. Karena itu, Yesus mengajarkan bahwa dalam kematian dan kebangkitan-Nya ada rekonsiliasi manusia dengan Tuhan, dan regenerasi dalam kehidupan baru secara spiritual.

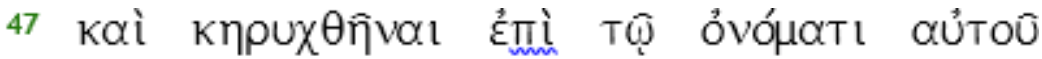

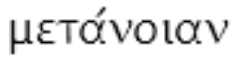 \\ And (should) be preached in his name that repentance}

Para murid akan dipanggil untuk berkhotbah atau memberitakan. Mereka mulai memenuhi panggilan ini dalam Kisah Para Rasul 2, dan sejak saat itu gereja telah memberitakan Yesus melalui firman yang diberitakan, bahkan Ia menjadi pusat dalam pemberitaan. Dalam frase ini, terdapat pertanyaan terkait dengan tensis aorist yang digunakan dalam kata kerja khruxqh=nai. Untuk menjawab pertanyaan tersebut, A Grammar of New Testament Greek memberikan jawaban demikian : Kata kerja infinitif partisip ini tidak memiliki fungsi temporal tetapi hanya menunjukkan jenis tindakan dan waktu tindakan disimpulkan dari konteks. Namun akhirnya frase ini 
menunjukkan waktu yang telah lewat jika dihubungkan dengan kata kerja utama. Karena itu perlu untuk melihat kasus ini demikian : banyak contoh aorist partisip di mana waktu aksi tidak mendahului kata kerja utama; ada frasa umum yang sama; tetapi ada juga yang kebalikannya (Moulton \& Turner, 1963, p. 79).

Penjelasan lain tentang bentuk aorist adalah adanya makna aspekstual: "Sudut Pandang Eksternal" yang berkenaan dengan kejadian secara keseluruhan atau ringkasan, termasuk titik awal dan titik akhir, tanpa merujuk pada peningkatan atau kemajuan internal - kontras dengan "Sudut Pandang Internal" dari present / imperfect. Dalam teks ini, kata kerja khruxqh=nai tergolong dalam Aorist Inseptif yaitu sebuah tindakan yang dimulai dari titik tertentu (Alkitab Sabda.Org, n.d.). Berikutnya juga istilah ini mendapat makna temporal yaitu suatu tindakan atau keadaan yang terlihat sebagai anteseden pada saat berbicara/menulis (dengan beberapa pengecualian). Bentuk ini disebut sebagai Implicit Conditional Proleptic Aorist: With participle, relative clause, or clause: John 15:8 (NRSV; better: "will be glorified"); Heb 4:10 (NIV; better: "will rest"). Istilah ini menunjuk pada sebuah keharusan untuk memberitakan berita dalam nama-Nya, mulai dari saat penderitaan dan kebangkitan Kristus yang telah diuraikan sebagai partisip sebelumnya.

Pesan kuat bagi para murid adalah panggilan untuk harus memberitakan pertobatan. Pertobatan dalam arti tidak hanya membahas "perubahan pikiran" yang disarankan oleh istilah Yunani metanoia tetapi "perubahan" yang terikat dalam konsep Ibrani tentang pertobatan. Pengertiannya secara lebih kuat berarti mereka yang membutuhkan hubungan dengan Tuhan dipanggil untuk berbalik kepada Tuhan dalam iman (Bock, 2010). Datang kepada Tuhan melibatkan kesadaran bahwa jalan yang dilaluinya adalah jalan yang salah. Mengenal Tuhan dalam pertobatan berarti mengubah arah hidup seseorang.

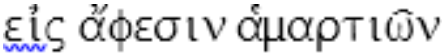 and remission of sins}

Ketika kita berpaling kepada Allah melalui Yesus, tawaran pengampunan memanifestasikan kesediaan Allah untuk bersikap ramah dan untuk membatalkan hutang dosa yang dibayar Yesus (Rm. 1 - Rm. 8, khususnya Rm. 3: 21-31). Wewenang untuk itu semua berada dalam nama Yesus. Inilah tema utama dalam Kisah Para Rasul. Peristiwa terkait dengan kehadiran pribadinya dan otoritas agungnya. Baptisan, penyembuhan dan pengampunan terutama dicatat dalam Kisah Para Rasul (Kis 2:38; Kis 2: 3: Kis 3: 6; Kis 4: 7; Kis 8:16; Kis 9: 15-16; Kis 10:43, Kis 10 : 48; Kis 15:14). Clarke menguraikan demikian, "Remission of sins $\alpha \varphi \varepsilon \sigma \mathrm{vv}$ $\alpha \mu \alpha \rho \tau i \omega v$, The taking away-removal of sins, in general every thing that relates to the destruction of the power, the pardoning of the guilt, and the purification of the heart from the very nature of sin (Clarke, 1999, p. 44). Pengampunan dosa dalam hal ini berhubungan dengan penghancuran kekuatan, pengampunan kesalahan, dan pemurnian hati dari sifat dosa. Pengampunan dosa ini telah dikerjakan oleh Yesus melalui penderitaan, kematian dan kebangkitan-Nya.

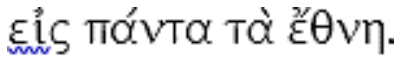
among all nations, 
Kata ini muncul dalam Perjanjian Baru sebanyak 162 kali, lebih sering memiliki arti Gentiles, a race (as of the same habit), a tribe; specially, a foreign (nonJewish) one (usually by implication, pagan). King James Version menerjemahkan Gentile, heathen, nation, people yaitu kafir, bangsa, orang. Ini berarti bahwa eis panta ta ethnē 'untuk semua bangsa', mengikuti kēruchthēnai, di mana ta ethnē di sini termasuk Israel. Penekanan kepada panggilan untuk semua orang dari segala suku, mengalami pertobatan dan menerima tawaran pengampunan. Gereja tidak hidup untuk dirinya sendiri; tetapi gereja dikirim ke seluruh dunia.

Selanjutnya, bagaimana gereja melakukan tanggung jawab pemberitaan ke segala bangsa dapat dilihat mulai dari Kisah Para Rasul 10. Awalnya para murid masih mengira bahwa Yesus meminta mereka berkhotbah untuk semua bangsa, kepada orang Yahudi di diaspora. Tetapi visi Allah kepada Petrus menunjukkan bahwa pesan itu untuk seluruh umat manusia. Yesus adalah Tuhan atas segalanya, sehingga pesannya dapat disampaikan kepada semua orang (Kis. 10: 34-43). Hal penting yang perlu diperhatikan adalah bahwa pemberitaan Injil ke segala bangsa selalu dikaitkan dengan kedatangan Tuhan Yesus yang kedua kali, sebagaimana tertera dalam Matius 24:14 (Morris, 1992, p. 602) Dalam konteks eskatologis, bahwa pemberitaan Injil akan terus dilakukan hingga kesudahan segala sesuatu, yaitu kedatangan Tuhan Yesus yang kedua kalinya.

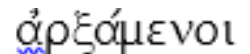

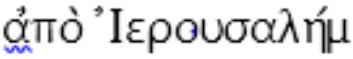

beginning at Jerusalem

Dan mengapa mereka harus mulai dari Yerusalem? Matthew Henry mengemukakan beberapa alasan : Pertama, karena Firman Tuhan harus dimulai dari Yerusalem, Yesaya 2: 3. Hal ini telah dinubuatkan sebelumnya dalam Yoel 2:32; 3:16; Obaja 21; Zakharia 14: 8. Kedua, karena kemuliaan Penebus yang bangkit telah mempermalukan Yerusalem sebagai pusat keagamaan. "Mulailah di Yerusalem, agar para imam kepala dapat mencoba kekuatan mereka untuk menghancurkan Injil, dan mungkin marah melihat diri mereka kecewa. " Ketiga, karena Ia akan memberi contoh lebih lanjut tentang memaafkan musuh. Yerusalem telah menempatkan penghinaan terbesar kepada Allah, namun tawaran rahmat Injil pertama kali diberikan ke Yerusalem, dan ribuan orang di sana dalam waktu singkat dibawa untuk mengambil bagian dalam rahmat itu (Henry, 1996, p. 36). Ketiga alasan ini menunjukan bahwa Allah telah merancang misi penyelamatan dunia secara terperinci. Apa yang dinubuatkan sebelumnya telah digenapi sesuai dengan kasih dan kemurahan-Nya. 


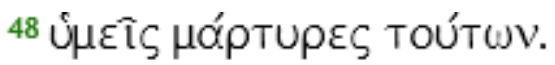 And ye are witnesses of these things}

Istilah saksi berasal dari kata martus (mar'-toos); a witness (literally [judicially] or figuratively [genitive case]); by analogy, a "martyr", berarti seorang saksi secara harfiah [secara hukum] atau secara kiasan [kasus genitif] dengan analogi, seorang "martir". Yesus mendefinisikan peran para murid sebagai saksi ( $\mu \alpha ́ \rho \tau \nu \varsigma$, martys) dari hal-hal ini (yang dimaksud dengan hal-hal ini adalah semua peristiwa yang telah diuraikan pada ayat sebelumnya). Kata kerja $\mu \alpha \rho \tau \nu \rho \varepsilon ́(\omega$ (martyreō, untuk bersaksi) juga digunakan dengan pengertian kesaksian para murid tentang peristiwa-peristiwa yang telah mereka lihat (Bock, 1996, p. 1941). Menurut Lukas, para rasul adalah "saksi" tidak hanya untuk peristiwa lahiriah dari kehidupan, kematian, dan kebangkitan Yesus, tetapi bagaimana para murid mengalami kuasa kematian dan kebangkitan-Nya secara pribadi. Bahkan dalam Kisah Para Rasul secara lebih dalam Lukas menyatakan tentang "saksi darah," yang menjadi saksi melalui penumpahan darahnya.

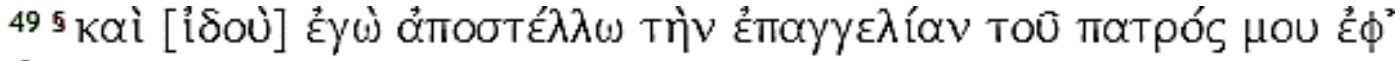

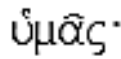

And, behold, I send the promise of my Father upon you:

Dalam ayat ini, dijelaskan bahwa Yesus yang mengirim apa yang dijanjikan oleh Bapa (Aku akan mengirim). Lukas menggunakan penjelasan yang sama dalam Kis 2:33 bahwa untuk mengalami kebaikan Bapa, seseorang harus melewati Anak. Lebih tajam penjelasan Lukas tentang janji Allah ini, menggambarkan kedatangan kuasa Roh Kudus yang memberikan kemampuan untuk bersaksi. Sebagaimana khotbah yang telah disampaikan oleh Yesus tentang Paraclete dalam Yohanes 14 - Yohanes 16 (Bock, 2010). Itu berarti dengan menyebut Allah "Bapa-Ku," Yesus menekankan hubungan intim mereka, yang juga terlihat dalam peran mediatorial Yesus. Roh

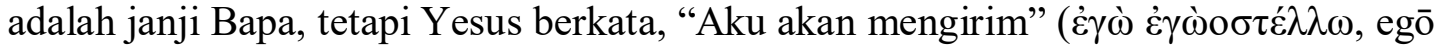
apostellō) kepadanya, dengan demikian menunjukkan bahwa ia memiliki wewenang atas distribusi Roh. Peran perantara Yesus ini cocok dengan uraian Petrus tentang distribusi Roh pada hari Pentakosta (Kisah Para Rasul 2: 30-33). Yesus adalah mediator dari manfaat dan janji keselamatan.

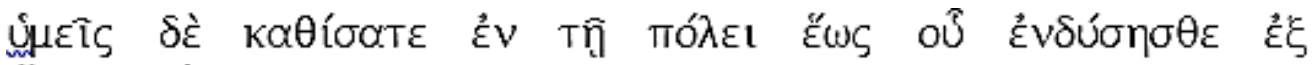

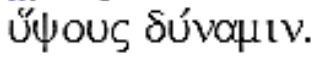

Ye but tarry ye in the city of (Jerusalem), until ye be endued with power from on high.
} 
Melalui kebangkitan-Nya, Yesus memiliki otoritas atas keselamatan. Dia adalah mediator yang menyalurkan janji-janji keselamatan Allah, kepada siapa saja yang hendak Ia berikan. Bagian ini mengarah pada instruksi kedua Yesus bahwa para murid harus pergi ke Yerusalem dan menunggu untuk berpakaian dari tempat tinggi (menunggu menggunakan kata $\kappa \alpha \theta i \zeta \omega$ [to sit] berarti "tetap" dalam Kisah Para Rasul 18:11; 1 Taw. 19: 5; Neh 11: 1-2). Istilah "diperlengkapi" digambarkan seperti seorang yang berpakaian tradisional, sebagaimana seringkali digunakan oleh Rasul Paulus (Rm. 13: 12-14; 1 Kor. 15:53; Gal. 3:27; Ef. 4:24; 6:11, 14; Kol. 3: 10, 12; 1 Tes. 5: 8) dan Yohanes (Wahyu 15: 6; 19:14). Ini adalah gambaran dalam Perjanjian Baru, yang merujuk pada berbagai karunia yang disediakan Allah bagi orang percaya, untuk "dikenakan" dalam perjalanan sehari-hari mereka. Selain itu, gambaran yang sama dalam Galatia 3:14 menunjukkan hubungan yang erat dengan realisasi janji Roh (Kittel, Gerhard, Bromiley, Geogfresy William; Friedrich, 1964, p. 76).

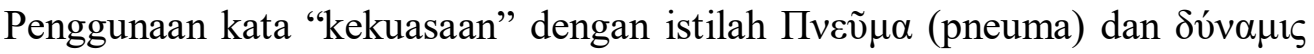
(dynamis) adalah istilah yang hampir sama karena kekuasaan adalah apa yang disediakan Roh (Mik. 3: 8; Lukas 1:17, 35; 4:14; Kisah 1: 5, 8; 6: 8; 10 : 38). Ketika

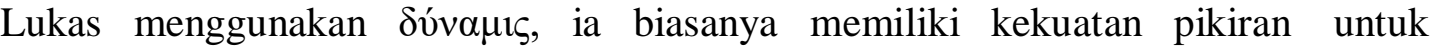
mengatasi kekuatan jahat, baik melalui mukjizat atau dengan otoritas Allah yang datang melalui Roh (Lukas 1:17; 4:36; 5:17; 6:19; 9: 1 ; 10:13, 19; Kisah Para Rasul 1: 8; 2:22; 3:12; 4:33; 6: 8; 8:13; 10:38; 19:11; Marshall 1970: 91-92). Dalam Lukas 9: 1 itu terkait dengan pemberitaan Injil, kerajaan, dan kuasa atas iblis dan penyakit. Firman dan pekerjaan adalah produk Roh. Selain itu, Roh memungkinkan keberanian untuk menyatakan pesan Allah (Kisah Para Rasul 1: 8). Karunia pemberdayaan khusus inilah yang harus ditunggu para murid di Yerusalem (Bock, 1996, p. 1943). Demikian Roh Kudus memperlengkapi para murid dengan kuasa untuk menjadi saksi Kristus yang dapat memproklamasikan Injil keselamatan disertai demonstrasi kuasa Allah untuk mengukuhan pelayanan misi mereka di tengah-tengah dunia.

\section{b. Titik Temu Kristologi dan Misiologi}

Berdasarkan struktur dan eksegesa di atas, dapat disimpulkan bahwa perkataan Yesus dalam teks ini menyatakan adanya kesatuan antara dua disiplin ilmu dalam teologi yaitu Kristologi dan Misiologi, yang disebut sebagai Integrasi. Integrasi Kristologi dan Misiologi akan menghasilkan keterlibatan dalam pelayanan misi dengan menjadi Saksi. Hal ini dibuktikan dalam eksegesa ayat 44 dalam frase "harus digenapi semua vang ada tentang Aku". Namun untuk memahami hal tersebut (integrasi kristologi dan misiologi) ada yang menghalangi (ayat 45). Ayat 44, kemudian diuraikan dalam bentuk infinitive menjadi sebuah keharusan (ayat 4647), yaitu harus menderita (kristologi), harus bangkit (kristologi) dan harus disampaikan (misiologi). Selanjutnya, dalam ayat 48 "kamu adalah saksi dari semuanva ini" (pelavanan misi). Dalam pelaksanaan sebagai saksi, harus tinggal di Yerusalem untuk diperlengkapi dengan kekuasaan dari tempat tinggi. 
Penelitian relevan yang dihasilkan melalui titik temu kristologi dan misiologi berdasarkan Lukas 24:44-49 adalah sebagai berikut :

\section{Kristologi}

1. Kristologi dibangun di atas dasar penggalian Firman Tuhan, "semua yang ada tertulis tentang Aku" (ayat 44).

2. Kristologi dapat dipahami hanya bila Tuhan telah membuka pikirannya (ayat 45).

3. Kristologi berpusat pada penderitaan, kematian hingga kebangkitan Kristus dari antara orang mati (ayat 46).

4. Tidak boleh berhenti hanya pada Kristologi, istilah "dan" menunjukan kesinambungan dengan hal berikutnya yaitu misiologi (ayat 47).

5. Kristologi sebagai awal (ayat 46), dilanjutkan misiologi (ayat 47), dan terlibat dalam misi (ayat 48)

Sintesa : Kristologi adalah pemahaman tentang Kristus yang dibangun di atas dasar penggalian Firman Tuhan, hanya dapat dipahami bila Tuhan membuka pikirannya, berpusat pada penderitaan hingga kebangkitan Kristus, dan tidak boleh berhenti melainkan dilanjutkan pada misiologi hingga terlibat dalam pelayanan misi dengan menjadi saksi.

\section{Misiologi}

1. Misiologi dibangun di atas dasar penggalian Firman Tuhan, "semua yang ada tertulis tentang Aku" (ayat 44).

2. Misiologi dapat dipahami hanya bila Tuhan telah membuka pikirannya (ayat 45).

3. Misiologi merupakan kesinambungan dari Kristologi (istilah "dan” di ayat 47).

4. Misiologi berfokus pada berita pertobatan dan pengampunan dosa (ayat 47).

5. Misiologi berisi berita tentang Kristus yang disampaikan kepada segala bangsa mulai dari Yerusalem. Persiapan sebagai saksi (ayat 49).

Sintesa : Misiologi merupakan kesinambungan dari kristologi, dibangun di atas dasar penggalian Firman Tuhan, hanya dapat dipahami jika Tuhan membukakan pikirannya. Misiologi sebagai persiapan terlibat dalam pelayanan misi, yang berfokus pada pemberitaan pertobatan dan pengampunan dosa di di dalam Kristus kepada segala bangsa dari Yerusalem.

\section{Pelayanan Misi}

1. Kamu adalah saksi berarti terlibat dalam pelayanan misi.

2. Seorang yang terlibat dalam pelayanan misi memiliki pemahaman Kristologi dan misiologi.

3. Seorang yang terlibat dalam pelayanan misi diperlengkapi dengan kekuasaan dari tempat tinggi (ayat 49) 



\section{Sintesa :}

Terlibat dalam pelayanan misi berarti menjadi saksi Kristus dengan pemahaman Kristologi dan Misiologis serta diperlengkapi dengan kuasa dari tempat yang tinggi (kuasa Roh Kudus)

Setelah sintesa atau kesimpulan sementara dapat dirumuskan maka selanjutnya disusun kerangka berpikir. Kerangka berpikir yang dihasilkan adalah kerangka berpikir yang asosiatif atau menjelaskan hubungan. (1) Kristologi merupakan dasar atau inti dari pemberitaan dalam pelayanan misi. Melalui Kristologi seorang bukan hanya mengetahui pribadi dan karya Kristus tetapi mengalaminya dengan percaya dan menerima Kristus dalam hatinya, akibatnya adalah memiliki gairah untuk bermisi, sikap misi dalam arah pengutusan. (2) Misiologi merupakan kelanjutan dari Kristologi dengan melihat misi Allah kepada manusia, maka manusia yang telah menerima keselamatan dari-Nya melanjutnya misi-Nya di tengah-tengah dunia. Pola Allah menyelamatkan manusia menjadi pola dalam pelayanan misi. (3) Adanya hubungan yang berkesinambungan mengakibatkan Integrasi Kristologi dan Misiologi akan memaksimalkan keterlibatan dalam pelayanan misi. Apalagi bila ditambah faktor lain yaitu diperlengkapi dari tempat tinggi.

Selanjutnya, berdasarkan kerangka berpikir di atas, maka tersusunlah hipotesa sebagai berikut :

1. Ada hubungan positif dan signifikan antara pemahaman kristologi dan keterlibatan jemaat dalam misi.

2. Ada hubungan positif dan signifikan antara pemahaman misiologi dan keterlibatan jemaat dalam misi.

3. Ada hubungan positif dan signifikan antara pemahaman kristologi dan misiologi terhadap keterlibatan jemaat dalam misi.

4. Ada faktor-faktor lain yang berhubungan langsung secara positif dan signifikan terhadap jemaat dalam misi.

\section{METODE PENELITIAN}

Penelitian dilaksanakan di Gereja POUK ICHTHUS BDP yang beralamat di Jalan Dirgantara Raya no 1 Kompleks Bumi Dirgantara Permai, Jatisari, Jatiasih, Bekasi, Jawa Barat, pada bulan April - Juni 2020.

\section{A. Desain Penelitian}

Metode penelitian kombinasi model atau desain sequential explanatory adalah metode penelitian kombinasi yang menggabungkan metode penelitian kuantitatif dan kualitatif secara berurutan, di mana pada tahap pertama penelitian dilakukan dengan menggunakan metode kuantitatif dan pada tahap kedua dilakukan dengan metode kualitatif. Metode kuantitatif berperan untuk memperoleh data kuantitatif yang terukur dan metode kualitatif berperan untuk membuktikan, memperdalam, dan memperluas data kuantitatif yang diperoleh pada tahap awal (Sugiyono, 2017, p. 415). 


\section{B. Langkah-Langkah Penelitian}

Langkah-langkah penelitian kombinasi desain/model sequential explanatory (urutan pembuktian) digambarkan sebagai berikut :

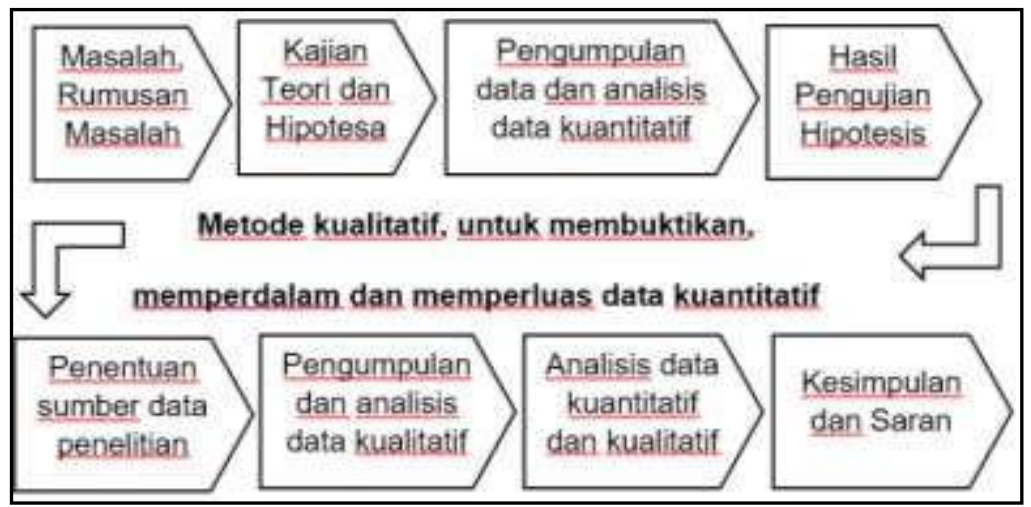

Gambar 1. Langkah penelitian (urutan pembuktian)

Dengan demikian penelitian kombinasi dilakukan untuk menjawab rumusan masalah penelitian kuantitatif dan rumusan masalah kualitatif, atau rumusan masalah yang berbeda, tetapi saling melengkapi.

\section{Metode Kuantitatif}

Penelitian ini dirancang ke dalam jenis penelitian survey dengan berfokus kepada analisa deskriptip-analitik, secara empiris. Digolongkan ke dalam penelitian survey (Depdikbud, 1985). Dengan tujuan untuk mendeskripsikan berbagai kejadian atau peristiwa, setiap masalah diidentifikasi agar dapat memperoleh justifikasi keadaan dan praktek-praktek yang telah berlangsung. Tujuan lainnya adalah untuk menguji hipotesis, menerangkan hubungan, interpretasi dan prediksi. Yang dimaksudkan dengan metode deskriptif ialah suatu metode penelitian yang berusaha mengumpulkan informasi tentang status suatu gejala yang ada, yaitu keadaan yang 'apa adanya' (Tindas, n.d.) untuk mendeskripsikan suatu variabel saat penelitian ini dilakukan. Metode deskriptif ini berbentuk survei dengan cara mendata informasi dari responden dengan menggunakan kuesioner, sebagai alat pengumpulan data pokok (Singarimbun, 1989, p. 3).

Penelitian korelasional menekankan "pola hubungan sebab akibat di antara variabel. Dan mencakup prediksi perilaku yang akan datang dari variabel yang diukur sebelum perilaku itu (Subagyo, 2004, p. 98). Tujuan penelitian korelasional ini adalah menemukan ada atau tidaknya hubungan antar variabel, jika ditemukan maka dicari seberapa kuat dan berartinya hubungan tersebut (Arikunto, 2002, p. 239). Dengan pengertian tersebut di atas, maka metode survey deskriptif korelasional cocok digunakan dalam penelitian ini, yaitu untuk memperoleh gambaran Integrasi Kristologi dan Misiologi bagi pelayanan misi di Gereja POUK ICHTHUS Bumi Dirgantara Permai. Adapun desain penelitian ini dapat digambarkan sebagai berikut : 


\section{a. Variabel Penelitian}

Berdasarkan hal tersebut, penelitian terhadap permasalahan ini dilakukan terfokus pada dua variabel independen yaitu pemahaman kristologi jemaat (X1) dan pemahaman misiologi jemaat (X2), serta satu variabel dependen yaitu keterlibatan jemaat dalam pelayanan misi (Y) (Telaumbanua, 2005, pp. 90-91). Rumusan masalah merupakan pertanyaan penelitian yang memandu peneliti untuk menentukan teori yang digunakan, perumusan hipotesis, penyusunan instrumen, pengumpulan data, analisis data dan membuat kesimpulan dan saran.

\section{b. Definisi Operasional}

Berdasarkan Lukas 24:44-49, maka pemahaman Kristologi yang dimaksudkan adalah : kristologi berdasarkan pada Alkitab, kristologi berfokus pada pribadi Kristus dan karya-Nya, kristologi berisikan berita pertobatan dan pengampunan dosa, kristologi yang mencakup segala bangsa, dan kristologi yang dapat dipahami dalam terang Roh Kudus. Sedangkan pemahaman misiologi yang dimaksud berdasarkan teks yang sama adalah : misiologi berdasarkan pada Alkitab, misiologi berfokus pada pribadi Kristus dan karya-Nya, misiologi berisikan berita pertobatan dan pengampunan dosa, misiologi yang mencakup segala bangsa, dan misiologi yang diberitakan dengan kuasa Roh Kudus. Selanjutnya, tentang keterlibatan jemaat dalam pelayanan misi, maka aspek yang dilihat adalah gairah misi, sikap misi dan ketajaman misi.

\section{c. Penetapan Populasi dan Sampel}

Populasi sasaran penelitian adalah jemaat dewasa Gereja POUK ICHTHUS Bumi Dirgantara Permai (ditandai dengan peneguhan sidi/baptisan dewasa), dengan karakteristik sebagai anggota dan bukan sekedar simpatisan dan rentang usia 18 sampai dengan 70 tahun. Dalam penelitian ini digunakan Simple Random Sampling, karena semua anggota populasi memiliki peluang yang sama dan tidak terikat untuk dimasukkan ke dalam sampel. Dengan jumlah populasi 1000 orang, tingkat kesalahan 5\%, dan perbedaan jumlah sampel yang diharapkan dengan yang terjadi $=$ 5\% (0,05). Jadi untuk populasi 1000 dengan tingkat kesalahan 5\%, jumlah sampelnya adalah 230 responden.

\section{d. Teknik Pengumpulan Data}

Pengumpulan data dalam penelitian ini dilakukan dalam setting alamiah (natural setting) dan mengambil lokasi di gereja POUK ICHTHUS Bumi Dirgantara Permai, di mana semua kegiatan dipusatkan. Pengumpulan data juga menggunakan sumber primer dan sumber sekunder. Teknik pengumpulan data dalam penelitian ini dilakukan dengan menggabungkan teknik interview (wawancara), kuesioner (angket), observasi (pengamatan). Participant Observation adalah sebuah penelitian yang melibatkan peneliti dalam kegiatan obyek penelitian. Sambil melakukan pengamatan, peneliti ikut melakukan apa yang dikerjakan oleh sumber data, dan ikut merasakan pengalaman di dalamnya. Hal ini sangat dimungkinkan karena keberadaan peneliti sebagai gembala jemaat di Gereja POUK ICHTHUS Bumi 
Dirgantara Permai, terlebih lagi bahwa peneliti telah melayani di gereja ini selama 22 tahun.

\section{e. Penetapan Instrumen Penelitian}

Untuk membangun suatu instrument, perlu ditentukan terlebih dahulu variabel yang akan dianalisis. Variabel bebas adalah Kristologi (X1) dan Misiologi (X2) yang terintegrasi dalam Misiokristi (X), sementara Variabel terikat adalah pelayanan misi yaitu pengutusan di Gereja POUK ICHTHUS BDP (Y). Variabel Kristologi (X1) memiliki lima (5) indikator yaitu : (1) Kristologi : bersumber dari Alkitab, dan (2) Kristologi : berfokus kepada Kristus (3) Kristologi : berita Pertobatan (4) Kristologi : untuk segala bangsa dan (5) Kristologi dalam terang Roh Kudus. Variabel Misiologi (X2) memiliki lima (5) indikator (1) Misiologi : bersumber dari Alkitab, dan (2) Misiologi : berfokus kepada Kristus (3) Misiologi : berita Pertobatan (4) Misiologi : untuk segala bangsa dan (5) Misiologi dalam kuasa Roh Kudus. Adapun variabel pelayanan misi (Y) memiliki tiga indikator yaitu : (1) Gairah Misi (2) Sikap Misi dan (3) Ketajaman Misi.

\section{f. Prosedur Penelitian}

Tahap persiapan ini meliputi kegiatan sebagai berikut: Proses perijinan, untuk memperoleh ijin operasional dalam melakukan penelitian. Dilanjutkan dengan melakukan pendataan dengan meneliti data sekunder, yaitu data sensus jemaat dan mulai menghubungi nara sumber, juga mempelajari pedoman kerja dan materi pembinaan jemaat sebagai referensi. Setelah instrumen penelitian selesai dikembangkan, selanjutnya diadakan uji coba instrument, yaitu uji validitas dan uji reliabilitas

\section{g. Tahap Uji Prasyarat Analisis}

Selanjutnya untuk tahap uji prasyarat analisis, pelaksanaan penelitian dimulai dengan pengumpulan data penelitian melalui penyebaran kuesioner kepada responden. Pengisian kuesioner dilakukan secara online menggunakan aplikasi google form (hal ini dilakukan mengingat masa pandemic covid 19 dengan adanya pemberlakuan social distancing. Langkah selanjutnya, mendata kuesioner yang telah diisi oleh responden, menyeleksi jawaban responden yang memenuhi syarat sesuai jumlah sampel yang dibutuhkan, mengkoding jawaban responden, penskoran, tabulasi data, analisis data, dan terakhir membuat keputusan analisis. Uji normalitas data bertujuan untuk menguji apakah data dari tiap-tiap variabel penelitian distribusi normal atau tidak. Uji linearitas digunakan untuk mengetahui apakah variabel bebas (X) dan variabel terikat (Y) mempunyai hubungan linear atau tidak. Persyaratan ini menuntut bahwa antar variabel bebas tidak boleh ada korelasi yang tinggi yaitu $r$ lebih besar dari 0.800 .

\section{h. Pengujian Hipotesis}

Analisis bivariant digunakan untuk menguji hipotesis pertama dan kedua yaitu untuk menguji koefisien antara variabel bebas dengan variabel terikatnya. 
Analisis ini digunakan untuk menguji hipotesis ketiga yaitu mencari koefisien kolerasi antara variabel bebas secara bersama-sama dengan variabel terikatnya. Melalui analisis ini akan didapatkan harga koefisien determinan (R2) hubungan antara dua variabel bebas secara bersama-sama dengan variabel terikatnya.

\section{Metode Kualitatif}

Penggunaan metode kuantitatif berakhir setelah hipotesis terbukti dan tidak terbukti. Untuk membuktikan hasil pengujian hipotesis secara kualitatif, dan untuk memperkuat dan memperdalam hasil penelitian kuantitatif dengan data kualitatif, maka dilanjutkan dengan menggunakan metode kualitatif. Metode kualitatif digunakan dengan tujuan untuk memperoleh data kualitatif guna menguji, memperluas, memperdalam hasil penelitian kuantitatif. Langkah-langkah dalam metode kualitatif adalah:

\section{a. Penentuan Sumber Data untuk Penelitian Kualitatif}

Titik tolak pengumpulan data dengan metode kualitatif adalah data yang terkumpul pada penelitian tahap pertama dengan metode kuantitatif. Data hasil penelitian kuantitatif adalah sebagai berikut :

a. Nilai variabel pemahaman kristologi

b. Nilai variabel pemahaman misiologi

c. Nilai keterlibatan jemaat dalam pelayanan misi

d. Nilai hubungan dan signifikansi pemahaman kristologi terhadap keterlibatan jemaat dalam pelayanan misi

e. Nilai hubungan dan signifikansi pemahaman misiologi terhadap keterlibatan jemaat dalam pelayanan misi

f. Nilai hubungan dan signifikansi pemahaman kristologi dan pemahaman misiologi terhadap keterlibatan jemaat dalam pelayanan misi

Penentuan sumber data dalam penelitian kualitatif didasarkan pada pertimbangan siapa orang yang paling tahu tentang apa yang ditanyakan dan dapat memberikan informasi yang valid. Karena itu peneliti menetapkan dua orang sebagai sumber data yaitu penasihat misi dan pendeta senior di Gereja POUK ICHTHUS Bumi Dirgantara Permai, selanjutnya pada bagian-bagian tertentu akan mengambil data dari 3 sumber yang adalah jemaat POUK ICHTHUS BDP, di luar dari sampel atau responden kualitatif.

\section{b. Analisis Data Hasil Penelitian Kuantitatif dan Kualitatif}

Analisis data kualitatif dan kuantitatif dilakukan dengan cara membandingkan data kuantitatif hasil penelitian kuantitatif yang dilakukan pada tahap pertama, dan data kualitatif hasil penelitian kualitatif tahap kedua. Melalui analisis data ini akan diperoleh informasi apakah kedua data saling melengkapi, memperluas, memperdalam atau malah bertentangan. Bila ditemukan kedua kelompok data ada yang bertentangan, maka data hasil penelitian kualitatif diuji kredibilitasnya lagi sampai ditemukan kebenaran data, dengan cara memperpanjang pengamatan, meningkatkan ketekunan, melakukan triangulasi, analisis kasus 
negative dan member check. Selanjutnya hasil penelitian yang digunakan adalah hasil penelitian kualitatif yang telah benar/pasti yang telah diuji kredibilitasnya.

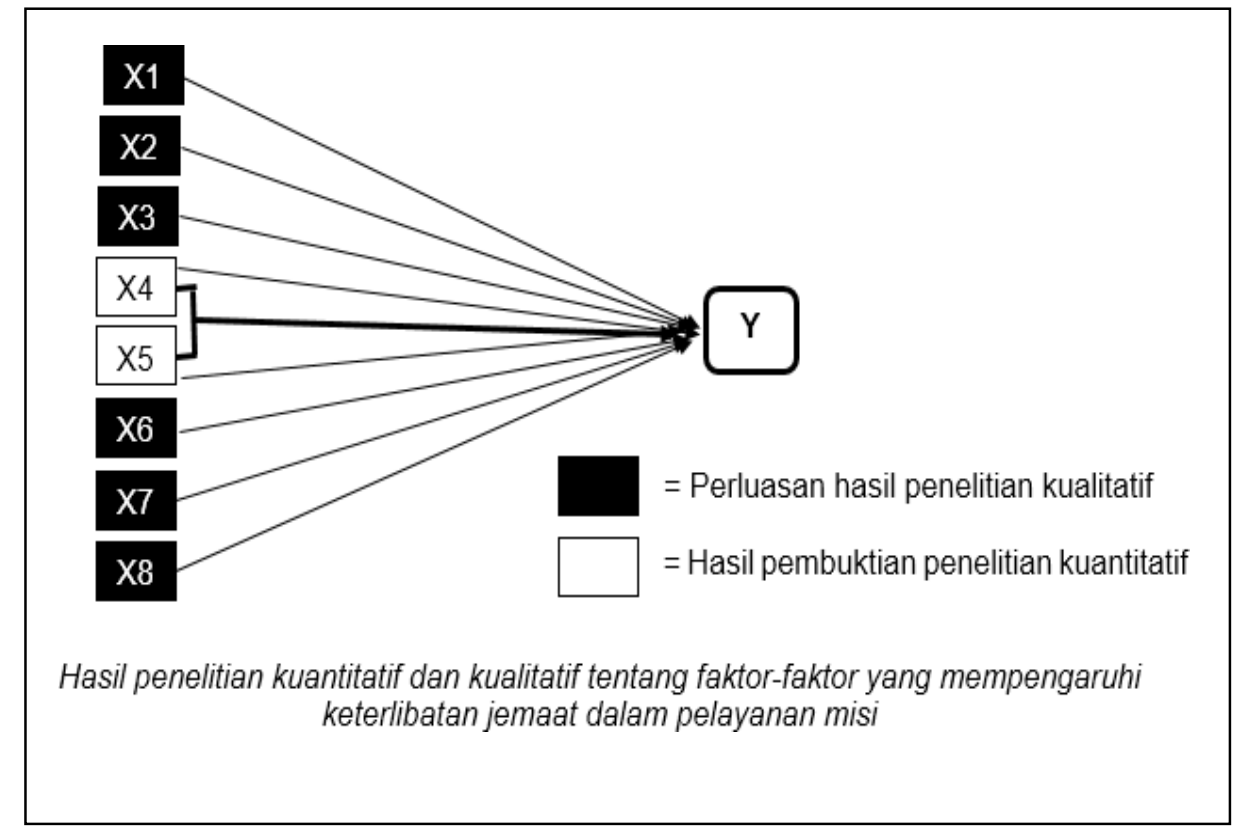

Gambar 3 Hasil Penelitian Kuantitatif dan Kualitatif

\section{HASIL DAN PEMBAHASAN}

\section{Pembahasan Hasil Penelitian}

a. Secara keseluruhan nilai kuantitatif pemahaman Kristologi sangat tinggi $=$ 95,2 (termasuk kategori sangat tinggi) dan secara kualitatif pemahaman Kristologi jemaat juga sangat baik, tidak ada perbedaan.

b. Secara keseluruhan nilai kuantitatif pemahaman Misiologi sangat tinggi = 93,04 (termasuk kategori tinggi) dan secara kualitatif pemahaman Misiologi jemaat juga baik, tidak ada perbedaan.

c. Secara keseluruhan nilai kuantitatif keterlibatan jemaat dalam Pelayanan Misi cukup tinggi $=80.8$ (termasuk kategori cukup tinggi) dan secara kualitatif pemahaman Misiologi jemaat juga cukup baik, tidak ada perbedaan.

d. Semua korelasi antar varibel tersebut signifikan yang berarti varibel tersebut mempunyai hubungan yang signifikan, karena dalam penelitian ini semua korelasi bernilai positif maka hubungan antar variabel tersebut berbanding lurus atau dengan kata lain dengan meningkatnya varibel Kristologi (X1), dan Misiologi (X2) maka akan meningkatkan variabel Pelayanan Misi (Y), 
Gairah Pelayanan Misi (Y1), Sikap Pelayanan Misi (Y2), dan Ketajaman Pelayanan Misi (Y3).

\begin{tabular}{|c|l|c|c|c|c|}
\hline No & \multicolumn{1}{|c|}{$\begin{array}{c}\text { Variabel yang } \\
\text { dikorelasikan }\end{array}$} & $\mathbf{r}$ hitung & $\mathbf{r}$ tabel & Keterangan & $\mathbf{r}^{2}$ \\
\hline 1 & $\begin{array}{l}\text { Kristologi dengan Pelayanan } \\
\text { Misi }\end{array}$ & 0.412 & 0,1294 & Signifikan & $\begin{array}{c}0.1 \\
70\end{array}$ \\
\hline 2 & $\begin{array}{l}\text { Misiologi dengan Pelayanan } \\
\text { Misi }\end{array}$ & 0.557 & 0,1294 & Signifikan & $\begin{array}{c}0.3 \\
33\end{array}$ \\
\hline 3 & $\begin{array}{l}\text { Kristologi dan Misiologi } \\
\text { dengan Pelayanan Misi }\end{array}$ & 0.579 & 0,1294 & Signifikan & $\begin{array}{c}0.3 \\
36\end{array}$ \\
\hline 4 & $\begin{array}{l}\text { Kristologi dengan Gairah } \\
\text { Pelayanan Misi }\end{array}$ & 0.391 & 0,1294 & Signifikan & $\begin{array}{c}0.1 \\
53\end{array}$ \\
\hline 5 & $\begin{array}{l}\text { Misiologi dengan Gairah } \\
\text { Pelayanan Misi }\end{array}$ & 0.569 & 0,1294 & Signifikan & $\begin{array}{c}0.3 \\
24 .\end{array}$ \\
\hline 6 & $\begin{array}{l}\text { Kristologi dan Misiologi } \\
\text { dengan Gairah Pelayanan } \\
\text { Misi }\end{array}$ & 0.574 & 0,1294 & Signifikan & $\begin{array}{c}0.3 \\
30\end{array}$ \\
\hline 7 & $\begin{array}{l}\text { Kristologi dengan Sikap } \\
\text { Pelayanan Misi }\end{array}$ & 0.462 & 0,1294 & Signifikan & $\begin{array}{c}0.2 \\
13\end{array}$ \\
\hline 8 & $\begin{array}{l}\text { Misiologi dengan Sikap } \\
\text { Pelayanan Misi }\end{array}$ & 0.643 & 0,1294 & Signifikan & $\begin{array}{c}0.4 \\
14\end{array}$ \\
\hline 9 & $\begin{array}{l}\text { Kristologi dan Misiologi } \\
\text { dengan Sikap Pelayanan } \\
\text { Misi }\end{array}$ & 0.646 & 0,1294 & Signifikan & $\begin{array}{c}0.4 \\
17\end{array}$ \\
\hline 10 & $\begin{array}{l}\text { Kristologi dengan } \\
\text { Ketajaman Pelayanan Misi }\end{array}$ & 0.332 & 0,1294 & Signifikan & $\begin{array}{c}0.1 \\
10 .\end{array}$ \\
\hline 11 & $\begin{array}{l}\text { Misiologi dengan Ketajaman } \\
\text { Pelayanan Misi }\end{array}$ & 0.449 & 0,1294 & Signifikan & $\begin{array}{c}0.2 \\
01\end{array}$ \\
\hline $\begin{array}{l}\text { Kristologi dan Misiologi } \\
\text { Pengan Ketajaman }\end{array}$ & 0.449 & 0,1294 & Signifikan & $\begin{array}{c}0.2 \\
02\end{array}$ \\
\hline
\end{tabular}

Tabel 1. Nilai Variabel yang di korelasikan

2. Dari hasil analisis regresi, jika variabel kristologi bertambah sebesar 1 poin maka variabel pelayanan misi akan berkurang sebesar 0.186 dengan asumsi variabel misiologi dianggap konstan, dan jika variabel misiologi bertambah 1 poin maka variabel pelayanan misi akan bertambah sebesar 1.067 dengan asumsi variabel kristologi diaggap konstan. Hasil negatif dari analisis regresi variabel Kristologi dengan Pelayanan Misi dilanjutkan dengan melihat regresi dari variabel Kristologi dengan indikator Pelayanan Misi 

(Y), yakni : Gairah Misi (Y1), Sikap Misi (Y2) dan Ketajaman Misi (Y3). Uji secara parsial dengan uji $T$, menghasilkan bahwa variabel Kristologi hanya memiliki pengaruh yang signifikan terhadap Sikap Pelayanan Misi, namun tidak memiliki pengaruh yang signifikan terhadap variabel Gairah Pelayanan Misi, dan Ketajaman Pelayanan Misi.

3. Hasil analisis regresi di atas menunjukkan harga koefisien determinasi $\left(\mathbf{r}^{2}\right)$ sebesar 0.336. Nilai tersebut berarti bahwa $33,6 \%$ perubahan pada variabel Pelayanan Misi (Y) dapat ditentukan oleh Kristologi (X1) dan Misiologi (X2), sedangkan 66,4\% dijelaskan oleh variabel lain yang tidak diteliti dalam penelitian ini.

4. Kesimpulan yang dapat di ambil dari analisis diatas jika diuji secara parsial dengan uji $\mathrm{T}$, bahwa varibel kristologi hanya memiliki pengaruh yang signifikan terhadap Gairah Misi, namun tidak memiliki pengaruh yang signifikan terhadap variabel Sikap Pelayanan Misi, dan Ketajaman Pelayanan Misi, Tetapi terjadi sebaliknya, jika di uji serentak dengan Uji F atau ANOVA, varibel kristologi, dan misiologi, memiliki pengaruh yang signifikan terhadap variabel Gairah Pelayanan Pelayanan Misi, Sikap Pelayanan Misi, maupun Ketajaman Pelayanan Misi.

Uji serentak menyampaikan tentang kekuatan Integrasi antara pemahaman Kristologi dan Misiologi yang berdampak pada keterlibatan jemaat POUK ICHTHUS Bumi Dirgantara Permai dalam pelayanan misi, baik dari segi gairah pelayanan misi, sikap dalam pelayanan misi dan ketajamannya dalam hal pengutusan misi global. Hipotesa dari penelitian ini terjawab demikian bahwa :

Pertama, ada hubungan positif dan signifikan antara pemahaman kristologi dan keterlibatan jemaat dalam misi.

Kedua, ada hubungan positif dan signifikan antara pemahaman misiologi dan keterlibatan jemaat dalam misi.

Ketiga, ada hubungan positif dan signifikan antara pemahaman kristologi dan misiologi terhadap keterlibatan jemaat dalam misi.

Keempat, ada variabel lain yang memiliki hubungan positif dan signifikan terhadap keterlibatan jemaat dalam misi.

Selain itu, peneliti mempresentasikan tema-tema yang ditemukan dalam penelitian sebagai model yang dapat menjadi acuan bagi Gereja POUK ICHTHUS Bumi DIrgantara Permai dan bagi gereja-gereja yang ingin menerapkan model ini :

1. Integrasi Kristologi dan Misiologi adalah pengajaran Kristologi dan Misiologi yang dibangun di atas dasar penggalian Alkitab (eksegesis).

Alkitab yang terdiri dari Perjanjian Lama dan Perjanjian Baru merupakan satu-satunya sumber pemahaman Kristologi dan Misiologi. Penggalian Alkitab yang tepat menjadi dasar untuk membangun doktrin atau pengajaran yang sehat dan 

menghasilkan praktik hidup kristiani yang berpadanan dengan Alkitab. Kristologi menguraikan secara mendalam tentang pribadi Kristus dan karya-Nya, sedangkan Misiologi tentang pola pengutusan, dimulai dari Allah Tritunggal mengutus Yesus Kristus, Yesus Kristus mengutus para murid-Nya dan gereja-Nya terlibat dalam pengutusan.

Program yang menekankan pengajaran Kristologi dan Misiologi telah diupayakan secara maksimal, hal ini terbukti melalui tingginya nilai pemahaman Kristologi dan Misiologi jemaat. Selanjutnya, promosi program dan variasi program, misalnya dengan merevisi buku pembinaan dengan membuatnya bibliologis, sistematis dan praktis, menggunakan metode pembelajaran yang inovatif, meningkatkan kualitas pengajar dengan memberi peluang belajar baik secara formal dan non formal. Semua pembenahan ini sebagai upaya menjangkau dan meningkatkan pemahaman jemaat dengan tetap konsisten pada pengajaran Kristologi dan Misiologi yang Alkitabiah.

\section{Integrasi Kristologi dan Misiologi berarti Kristologi yang misiologis dan Misiologi yang kristologis.}

Kristologi yang misiologis berarti kristologi yang bermuara pada misi atau pengutusan sedangkan misiologi yang kristologis berarti misiologi untuk pemberitaan tentang Kristus, baik pribadi maupun karya-Nya. Pemahaman tentang pribadi dan karya Kristus dibarengi dengan pemahaman tujuan pengutusan Kristus ke tengah-tengah dunia, demikian pula gereja mengutus jemaat diutus ke seluruh dunia untuk menyampaikan tentang pribadi dan karya Kristus.

Revisi perlu dilakukan untuk materi pembinaan dengan menekankan pribadi dan karya Kristus dalam pemberitaannya. Hal ini dapat dilakukan dengan membuat atau mempertajam materi Pemberitaan Injil (PI) yang terfokus kepada Kristus dan bukan hanya sekedar kesaksian pengalaman pribadi tentang pertobatan.

\section{Integrasi Kristologi dan Misiologi terdapat hubungan demikian : Kristologi tanpa Misiologi menjadi Kristologi tanpa sasaran, Misiologi tanpa Kristologi menjadi Misiologi tanpa dasar.}

Poin tiga ini hampir menyerupai poin yang sebelumnya, hanya saja bagian ini lebih banyak memandang resiko atau akibatnya jika tidak memperhatikan korelasi (integrasi) antara Kristologi dan Misiologi. Kristologi tanpa misiologi disebut sebagai kemandulan karena tidak dapat menghasilkan buah, sedangkan Misiologi tanpa Kristologi menjadi tanpa arah. Jika pemahaman Kristologi hanya sebatas mengisi pengetahuan, maka itu akan menjadi penghambat misi, sedangkan Misiologi tanpa disertai dengan pengajaran Kristologi, jika hanya sebatas membakar gairah atau semangat maka dapat melahirkan penyesatan.

Kristologi tidak dapat berjalan sendirian demikian pun Misiologi. Keduanya harus menjadi bagian dalam pengajaran kepada jemaat. Untuk membenahi kondisi ini, yang dapat dilakukan adalah memasukan materi misiologi dengan porsi yang lebih besar untuk mengimbangi pengajaran Kristologi, selain itu para pengajar perlu untuk dipersiapkan dalam penyampaian pengajaran agar tidak mengabaikan 
penekanan misiologi dalam setiap kesempatan memberi pengajaran Kristologi. Selain itu, tema-tema khotbah tahunan yang bertemakan misi dapat lebih ditingkatkan porsinya untuk mengimbangi khotbah pengajaran Kristologi.

\section{Integrasi Kristologi dan Misiologi menambah mutu pelayanan misi.}

Meningkatnya pemahaman Kristologi dan Misiologi secara bersamaan, akan mempengaruhi penambahan kualitas pelayanan misi. Adapun unsur-unsur yang terdapat dalam pelayanan misi adalah gairah atau dapat disebut sebagai belas kasihan terhadap orang yang belum diselamatkan, sikap misi yaitu misi biasa yang dapat disebut melaksanakan Pemberitaan Injil (PI) kepada saudara-saudara yang tinggal di sekitar rumah, dan akhirnya pada ketajaman misi, yaitu pelayanan misi global, terlibat aktif dalam pelayanan terhadap suku-suku yang terabaikan. Hal ini dapat berlaku sebaliknya, yaitu jika pelayanan misi kurang berkualitas, maka ada kemungkinan bahwa pengajaran Kristologi dan Misiologi masih kurang maksimal.

Program yang diusulkan untuk memfasilitasi hal ini adalah keterlibatan jemaat pada pelayanan internal, yaitu visitasi kepada jemaat sendiri, untuk mendapatkan konfirmasi bahwa jemaat yang dikunjungi telah percaya dan menerima Yesus sebagai Tuhan dan Juruselamat. Selain itu, pelayanan eksternal seperti pelayanan ke rumah sakit-rumah sakit, Lembaga Pemasyarakatan, jemaat dapat terlibat dalam perjalanan misi (Short Term), baik di dalam maupun luar negeri.

\section{Integrasi Kristologi dan Misiologi yang diajarkan secara maksimal akan menghasilkan keterlibatan dalam misi global.}

Bila bobot pengajaran Kristologi dan Misiologi ditambah dan pengajaran dilakukan secara serentak, maka bobot keterlibatan jemaat dalam pelayanan misi pun akan semakin bertambah. Jika dikaitkan dengan progress keterlibatan jemaat dalam misi, maka jemaat tersebut dapat mencapai angka maksimal dalam ketajaman misi. Ketajaman misi yang dimaksudkan adalah keterlibatan jemaat dalam misi global yaitu pengutusan kepada suku-suku yang terabaikan (STA), yaitu wilayah fokus misi yaitu suku yang orang percayanya masih kurang dari $1 \%$ dan belum ada gereja pribumi yang berdiri serta kebanyakan berada di wilayah yang miskin.

Untuk peningkatan program yang terkait dengan ketajaman misi adalah pemberitaan Injil (PI) kepada saudara-saudara yang berada di sekitar Gereja POUK ICHTHUS BDP, mereka dari STA yaitu suku S dan B. Keberadaan Gereja POUK ICHTHUS BDP sudah lebih dari 20 tahun di sana, namun pengaruh penanaman Inji kepada mereka masih sangat terbatas, dalam arti masih bersifat ribadi pribadi. Gereja seharusnya mulai memikirkan secara serius bagaimana menjangkau mereka yang dekat tetapi "jauh". Hal ini mungkin dilakukan dengan pendekatan kontekstual sehingga Injil dapat disampaikan. Pelatihan dan Kursus yang terkait dengan pelayanan terhadap saudara-saudara ini sangat dibutuhkan sebagai wadah ketajaman misi. 


\section{Integrasi Kristologi dan Misiologi terintegrasi dalam kehidupan sebagai Saksi Kristus yang ditandai dengan ketaatan.}

Pengajaran Kristologi dan Misiologi disampaikan bukan hanya sekedar mengisi pengetahuan tetapi harus diresponi sehingga dapat membangun pribadi yang memiliki kerohanian kuat. Istilah yang digunakan dalam frase "kamu adalah saksi dari semuanya ini", adalah "saksi" atau "martyr". Kamu menunjuk kepada para murid, yaitu pribadi yang telah dimentoring lebih dari 3,5 tahun oleh Tuhan Yesus. Merekalah yang diharapkan untuk melanjutkan apa yang telah Tuhan kerjakan di dalam diri Yesus Kristus. Ciri dari pribadi murid adalah ia hidup dalam ketaatan kepada Tuhan.

Pembenahan yang perlu dilakukan adalah adanya multiplikasi murid Kristus dalam proses mentoring. Memang sebagian utusan dan jemaat yang bermitra sebagai pengutus secara aktif adalah buah dari mentoring, namun masih ada banyak kelompok kecil yang belum efektif membentuk murid Kristus. Baik sebagai Mentor rohani atau pun sebagai Murid, pengajaran Kristologi dan Misiologi yang dapat diteladani akan berbicara lebih kuat kepada jemaat.

\section{Faktor lain yang mengefektifkan Integrasi Kristologi dan Misiologi adalah adanya kekuasaan dari tempat tinggi yaitu kuasa Roh Kudus.}

Faktor lain yang mepengaruhi keterlibatan seorang dalam misi adalah adanya kuasa Roh Kudus yang bekerja di dalam dirinya. Pada saat Pentakosta, para murid dipenuhi oleh Roh Kudus dan mereka mengatakan tentang perbuatan besar Tuhan dalam berbagai bahasa. Ini menunjukan bahwa Roh Kudus adalah sumber kekuatan dalam misi. Efektivitas pelayanan misi sangat bergantung dari peran Roh Kudus yang bekerja dalam diri orang yang telah percaya, tetapi juga dalam diri orang yang belum percaya.

Jemaat POUK ICHTHUS BDP telah mengalami pertobatan (dapat dilihat dalam lampiran data responden) melalui pelayanan pribadi atau pun acara-acara di dalam gereja, dan sejak saat itu Roh Kudus hadir dan berkuasa dalam dirinya, ditandai dengan hati yang penuh dengan belaskasihan terhadap orang yang belum percaya, tetapi juga keberanian untuk menyampaikan Injil yang menyelamatkan. Persekutuan Doa Satu Jam setiap pagi di gereja, doa berantai dan doa puasa, menjadi kekuatan terjadinya kegerakan misi di gereja POUK ICHTHUS BDP, baik bagi kegerakan misi internal gereja sebagai pengutus, maupun kegerakan misi di ladang, dalam pelayanan para Tenaga Utusan Gereja karena ada faktor pendukung dari tempat tinggi, yaitu Roh Kudus melalui doa-doa yang dipanjatkan. 


\section{SIMPULAN}

Hasil analisis regresi nilai pengaruh Kristologi dan Misiologi terhadap keterlibatan jemaat dalam misi sebesar 33,6\% sehingga 66,4\% dapat dicapai dengan peningkatan pengajaran Kristologi dan Misiologi (substansi) atau penemuan variabel lain, sebagaimana terdapat di dalam model yang ditemukan dalam penelitian ini. Model Integrasi Kristologi dan Misiologi bagi Pelayanan Misi di Gereja POUK ICHTHUS BDP dengan beberapa poin penting: (1) Integrasi Kristologi dan Misiologi adalah Kristologi dan Misiologi yang dibangun di atas dasar penggalian Alkitab (eksegesis). (2) Integrasi Kristologi dan Misiologi berarti Kristologi yang misiologis dan Misiologi yang kristologis.

(3) Hubungan dalam Integrasi Kristologi dan Misiologi adalah Kristologi tanpa Misiologi menjadi Kristologi tanpa sasaran, Misiologi tanpa Kristologi menjadi Misiologi tanpa dasar. (4) Integrasi Kristologi dan Misiologi berdampak pada kualitas pelayanan misi. (5) Integrasi Kristologi dan Misiologi yang maksimal menghasilkan keterlibatan dalam misi global. (6) Integrasi Kristologi dan Misiologi yang terintegrasi dalam hidup seseorang dapat membentuk sosok Saksi Kristus yang taat. (7) Faktor lain yang mengefektifkan Integrasi Kristologi dan Misiologi adalah kekuasaan Roh Kudus.

Model Integrasi Kristologi dan Misiologi ini lahir dari perjalanan pelayanan gereja POUK ICHTHUS BDP dalam menaati visi yang telah Tuhan berikan untuk menjadi jemaat yang oikoumenis dan misioner. Melalui model Integrasi Kristologi dan Misiologi ini, Gereja POUK ICHTHUS BDP terus membenahi diri untuk melakukan tugas utamanya secara maksimal dan berkelanjutan, hingga segala suku kaum dan bahasa di seluruh dunia menyembah Yesus sebagai Tuhan dan Raja, sampai kedatangan Tuhan Yesus yang kedua kali.

Berdasarkan apa yang telah disimpulkan pada bagian sebelumnya, peneliti menyampaikan sejumlah rekomendasi yaitu kepada Gembala Jemaat, Para Pengajar Kelas Pembinaan Jemaat dan Penggiat Misi di Gereja POUK ICHTHUS Bumi Dirgantara Permai dan di gereja-gereja mitra misi. Rekomendasi ini dibuat berdasarkan model yang ditemukan dalam penelitian ini. Adapun pemaparannya adalah sebagai berikut :

\section{Pertama, kepada Gembala Jemaat.}

Pengajaran Kristologi dan Misiologi telah diupayakan secara maksimal, hal ini terbukti melalui tingginya nilai pemahaman Kristologi dan Misiologi jemaat. Pembaharuan program yang diusulkan : merevisi buku pembinaan 1-4 sesuai prinsip-prinsip dalam model Integrasi Kristologi dan Misiologi baik secara bibliologis, sistematika dan praktis, menggunakan metode pembelajaran yang inovatif, meningkatkan kualitas pengajar dengan memberi peluang belajar baik secara formal dan non formal. Dipandang perlu untuk mempertajam materi dalam pelatihan penginjilan baik kepada orang Kristen yang disebut Re-Evangelisasi atau pun bagi non Kristen. Revisi perlu dilakukan untuk mempertajam materi pelatihan dengan menekankan pribadi dan karya Kristus dalam pemberitaannya dan bukan hanya sekedar kesaksian pengalaman pribadi tentang pertobatan.

Gereja POUK ICHTHUS BDP memiliki kecenderungan untuk lebih menekankan pengajaran Kristologi daripada misiologi. Untuk membenahi kondisi ini, yang dapat dilakukan adalah menambahkan materi misiologi dengan porsi yang lebih besar untuk mengimbangi pengajaran Kristologi, selain itu para pengajar perlu untuk dipersiapkan dalam penyampaian pengajaran agar tidak mengabaikan penekanan misiologi dalam setiap kesempatan memberi pengajaran Kristologi. Keterlibatan jemaat POUK ICHTHUS BDP dalam pelayanan misi tergolong tinggi, dapat dipahami karena sejak awal mula berdirinya gereja, Kristologi dan Misiologi terus menjadi pusat pemberitaan. Yang perlu dipikirkan adalah bagaimana memfasilitasi gairah, sikap dan ketajaman misi dari jemaat POUK ICHTHUS BDP. Pelatihan penginjilan baik untuk kalangan Kristen maupun non Kristen 
perlu ditingkatkan. Selanjutnya jemaat diberi kesempatan untuk mempraktikannya baik di dalam gereja yaitu kepada jemaat sendiri, maupun kepada mereka yang berada di luar gereja. Baik pelatihan maupun program dapat dilakukan secara regular dengan tujuan menjaga api penginjilan.

Ketajaman misi adalah bagian dari pelayanan misi yang paling kecil nilainya (37\%) bila dibandingkan dengan gairah misi (65\%) dan sikap misi (67\%). Meskipun jumlahnya kecil namun bagian ini perlu untuk dipelihara dengan baiUntuk peningkatan program yang terkait dengan ketajaman misi adalah pemberitaan Injil (PI) kepada saudara-saudara yang berada di sekitar Gereja POUK ICHTHUS BDP, mereka dari STA yaitu suku S dan B. Keberadaan Gereja POUK ICHTHUS BDP sudah lebih dari 20 tahun di sana, namun pengaruh penanaman Inji kepada mereka masih sangat terbatas, dalam arti masih bersifat pribadi pribadi. Kualifikasi mentor perlu diperhatikan tetapi juga strategi dalam multiplikasi murid Kristus masih perlu ditingkatkan. Secara khusus untuk PD Timotius sebagai wadah bagi jemaat yang terpanggil melayani sepenuh waktu untuk menjadi pendeta atau misionaris, perlu mendapat perhatian khusus untuk proses mentoring dari gembala jemaat. Kegerakan doa menjadi ciri yang mengawali kegerakan misi, karena itu gereja perlu memfasilitasi kehidupan doa jemaat secara khusus yang diarahkan pada pelaksanaan misi global, disarankan untuk mendoakan pintu penginjilan agar terbuka dan yang kedua agar Tuhan memberikan keberanian untuk bersaksi tentang Tuhan.

\section{Kedua, kepada para pengajar / pengkhotbah / mentor Gereja POUK ICHTHUS Bumi Dirgantara Permai}

Para pengajar perlu mempersiapkan diri secara maksimal untuk menyampaikan pengajaran Kristologi dan Misiologi secara bibliologis, proporsional dan praktis. Karena itu pengajar harus terbuka diperlengkapi baik secara formal maupun non formal. Pengkhotbah perlu menyampaikan tema-tema khotbah tahunan yang bertemakan misi dengan porsi yang lebih untuk mengimbangi khotbah pengajaran Kristologi. Pemahaman misiologi yang disertai contoh-contoh praktik misi perlu untuk disampaikan dalam khotbah-khotbah kepada jemaat. Sosok pengajar atau pengkhotbah yang misioner akan sangat kuat membangkitkan gairah misi dan mempertajam pelayanan misi ke arah misi global. Dalam arti pengajar atau pengkhotbah tidak hanya berbicara tentang misi tetapi menghidupinya sehingga pengajarannya lebih efektif dan memberi dampak. Kualifikasi mentor adalah hidup sebagai saksi Kristus. Selain itu, perlu untuk belajar dari Yesus tentang strategi untuk menjangkau keluar dan menumbuhkan yang di dalam, yakni sebuah strategi dalam multiplikasi murid Kristus. Secara khusus untuk PD Timotius sebagai wadah bagi jemaat yang terpanggil melayani sepenuh waktu untuk menjadi pendeta atau misionaris, perlu mendapat perhatian khusus untuk proses mentoring dari gembala jemaat. Mentor bukan sekedar mengajar tetapi membimbing agar terjadi perubahan untuk memiliki karakter misi.

\section{Ketiga, kepada gereja-gereja mitra misi POUK ICHTHUS BDP}

Gereja-gereja mitra dapat menggunakan buku pembinaan jemaat dengan model integrasi Kristologi dan Misiologi untuk melibatkan jemaat dalam pelayanan misi. Gerejagereja mitra dapat menggunakan materi Re-Evangelisasi untuk pemberitaan Injil bagi jemaat yang belum mengalami kelahiran baru. Gereja-gereja mitra misi dapat menggunakan tema-tema tahunan yang sarat dengan pengajaran Kristologi dan Misiologi. Gereja-gereja mitra misi dapat memulai pola pemuridan untuk mementoring jemaat yang sudah mulai terlibat dalam pelayanan misi agar memiliki ketajaman misi sampai kepada misi global. Gereja-gereja misi mendoakan para pelayan di gerejanya menjadi pelayan yang kuat dari sisi pengajaran tetapi memiliki hati misi. 


\section{DAFTAR PUSTAKA}

Alkitab Sabda.org. (n.d.). https://alkitab.sabda.org/strong.php?id=5777

Arikunto, S. (2002). Prosedur Penelitan Pendekatan Praktek. Rineka Cipta.

Bock, D. L. (1996). Luke. In Grand Rapids:Baker Book: Vol. Volume 2:9.

Bock, D. L. (2010). Luke, The IVP New Testament Commentary Series. IVP Academic.

Bosch, D. J. (1991). Transformasi Misi Kristen: Sejarah Teologi Misi yang Mengubah dan Berubah. BPK Gunung Mulia.

Clarke, A. (1999). Clarke's Commentary: Luke. (electronik ed. Albany.or). Ages Software

Depdikbud. (1985). Materi Dasar Pendidikan Program Akta Mengajar V, Buku I B, Metodologi Penelitian. Universitas Terbuka.

Elwood, D. J. (1992). Teologi Kristen Asia: Tema-tema yang tampil ke Permukaan. BPK Gunung Mulia.

Henry, M. (1996). Matthew Henry's Commentary on the Whole Bible: Complete and Unabridged in One Volume. Peabody: Hendrickson.

Jenkins, P. (2011). The Next Christendom: The Coming of Global Christianity. Oxford University Press.

Kantzer, K. S. (1996). Systematic theology as a practical discipline. Doing Theology for the People of God, 21-41.

Kittel, Gerhard, Bromiley, Geogfresy William; Friedrich, G. (1964). Theological Dictionary of the New Testament (electronic ed.,). Grand Rapids, MI:Eerdmans.

Larry, P. (n.d.). Tense Voice Mood, Ontario : Woodside Bible Fellowship.

Maclaren, A. (2008). Expositions of Holly Scripture. Heritage Educational System.

Morris, L. (1992). Expositions of Holy Scripture, Heritage Education Systems. W.B. Eerdemans; Inter-Varsity Press.

Moulton, J. H., \& Turner, N. (1963). A Grammar of New Testament Greek: Syntax, by N. Turner (Vol. 3). T. \& T. Clark.

R.W Stott, J. (1996). Theology: A Multidimensional Dicipline, Doing Theology for the People of God (L. A. Donald Lewis and Alister Mc Grath (Ed.)). Appolos.

Robertson, A. . (2006). A Grammar of the Greek New Testament in the Light of Historical Research, Logos.

Singarimbun, M. (1989). Metode Penelitian Survey. LP3ES.

Strong, J. (1996). The Exhaustive Concordance of the Bible: Showing Every Word of the Test of the Common English Version of the Canonical Books, and Every Occurence of 
Word in Regular Order. (electronic ed.). Woodside Bible Fellowship.

Subagyo, A. B. (2004). Pengantar Riset Kuantitatif dan Kualitatif. Bandung: Kalam Hidup.

Sugiyono. (2017). Metode Penelitian Kombinasi (Mixed Method). Alfabeta.

Telaumbanua, F. (2005). Pengelolahan Data Penelitian Perbandingan dan Hubungan. Fakultas Keguruan dan Ilmu Pendidikan, UKI.

Tindas, A. (n.d.). Research Methodology. STT Harvest.

Van Engen, C. (1996). Mission on the Way: Issue in Mission Theology (Grand Rapi). Baker Boks.

Van Engen, C. (2000). Reformed Mission, Evangelical Dictionary of World Mission (Grand Rapi). Baker Boks.

Verkuyl, J., \& Cooper, D. (1978). Contemporary missiology: An introduction. Eerdmans.

Viner, W.E., Unger, Merril F., White, W. (1996). Vine's Complete Expository Dic. Dictionary of Old and New Testament Words. T. Nelson.

www. Getreligion.org. (n.d.). Retrieved November 16, 2019, from www. Getreligion.org 